\title{
Futsal improve body composition and cardiorespiratory fitness in overweight and obese children. A pilot study
}

\author{
Paulo Roberto Santos-Silva ${ }^{1}$, Júlia Maria D’Andrea Greve ${ }^{1}$, Hector Norman Espada Novillo', Sandra Haddad ${ }^{1}$, \\ Claudia Renata Pinto Santos ${ }^{2}$, Renata Barco Leme², Ruth Rocha Franco ${ }^{2}$, Louise Cominato ${ }^{2}$, Alessandra Teixeira \\ Miranda Araújo ${ }^{2}$, Fernando Miranda Santos ${ }^{2}$, Durval Damiani ${ }^{2}$, Roberta Luksevicius Rica ${ }^{3}$, Danilo Sales Bocalini ${ }^{4}$ \\ ${ }^{1}$ Universidade de São Paulo, USP, Faculdade de Medicina, laboratório de Estudos do Movimento, LEM, do \\ Instituto de Ortopedia e Traumatologia, Hospital das Clínicas, Centro de Excelência da FIFA e da FIMS, São \\ Paulo, SP, Brazil; ${ }^{2}$ Universidade de São Paulo, USP, Faculdade de Medicina, Endócrino-Pediatria do Instituto da \\ Criança, Hospital das Clínicas, de São Paulo, SP, Brazil, ${ }^{3}$ Universidade São Judas Tadeu, USJT, Programa de Pós- \\ Graduação em Educação Física, São Paulo, SP, Brazil, ${ }^{4}$ Universidade Federal do Espirito Santo, UFES, Laboratório \\ de Fisiologia e Bioquímica Experimental, Centro de Educação Física e Desportos, Vitória, ES, Brazil.
}

\begin{abstract}
Aims: The aim of this study was to verify body composition, cardiorespiratory fitness, and biochemical markers of prepubertal overweight and obese boys to a 16-week futsal training program. Methods: Sixteen boys (age: 7-10 y, body mass index $>$ thanat 95 th percentileaccording to Center for Disease Control and Prevention; $35.5 \pm 7.4$ percent fat) participated to futsal training program. The assessment of body composition was estimated using skinfold thickness, and the following variables were evaluated: total body mass, body mass index, body fat percentage, and lean body mass. Aerobic fitness measurementwas performed by gas exchange analysis in treadmill. In addition, an evaluation of the biochemical profile was conducted: triglycerides, total cholesterol, low density lipoprotein cholesterol, high-density lipoprotein cholesterol, plasma concentrations of glucose, and insulin. The futsal intervention included 60-min sessions performed two times/week. The mean intensity during training was between 57 to $88 \%$ of maximal heart rate of the age-predicted. Individual portable heart rate monitor controlled training intensity. Results: Significant increases in total body mass (4\%), height (3\%), lean body mass (8\%), and significant $6 \%$-decrease in body fat percentage was observed. Body mass index remained unchanged. Maximal oxygen uptake was elevated $(\mathrm{p}<0.018)$ by $11 \%$. Biochemical markers were not modified after intervention. No association was found between body composition and metabolic variables. The effect size of futsal training on most variables was small $(<0.5)$. Conclusion: Controlled intensity and adherence to this 16 -week futsal training program were determinant to enhance body composition, and cardiorespiratory fitness in this group of prepubertal boys.
\end{abstract}

Keywords: maximal oxygen uptake, lean body mass, fat mass percentage, overweight.

\section{Introduction}

Futsal and soccer are two sports with many similarities, but the striking difference between them is the size of the field, rules of the game, and tactical actions ${ }^{1}$. Soccer is a sport that beyond the force of social inclusion is a powerful tool for health in all ages including a reduction in the risk of cardiovascular diseases, falls, and fractures ${ }^{2}$. Soccer affects positively numerous cardiovascular risk factors such as oxygen uptake, heart function, blood pressure, insulin resistance, cholesterol, and fat mass far more than strength training, and just in as much as running ${ }^{3}$.

Nevertheless, several studies have investigated the effects of recreational soccer but almost none have addressed the futsal play on lipid and cardiovascular risk markers in overweight and obese children. Moreover, most of the applied research programs are not exclusively based on soccer practice ${ }^{4}$ and even more difficult with futsal, since markers are very restricted in cardiovascular risk ${ }^{5}$.

In brief, there is a lack of research on the efficacy of healthoriented sports programs for overweight and obese children with health markers, and that is one reason why we use futsal as this sport is widely practiced in school. According to Hallal,
Andersen, Bull, Guthold, Haskell, Ekelund ${ }^{6}$, approximately four in five adolescents do not achieve the recommended quantity and quality of daily exercise for health. Therefore, futsal may be the additive to activate metabolism and act as a cofactor to fight against overweight and obesity ${ }^{7}$. In relation to the higher contribution in futsal, we hypothesize that it is at least as efficacious as a standard exercise program in improving health and fitness in overweight and obese children. Thus, the aim of this study was to determine whether a recreational futsal training program would induce any chronic effects on total body mass, body fat percentage, lean body mass, maximal oxygen uptake (VO2max) performance, and biochemical markers modification.

\section{Materials and Methods}

\section{Participants and study design}

Participants were recruited from the outpatient clinic of the pediatric endocrinology department of the Children's Institute 
of the Hospital das Clinicas de Sao Paulo. This research follows a one-group pre and post-interventional design for 16-week for recreational futsal training. After explaining the objectives of the study, the parents of the children signed the informed consent form for participation. University of São Paulo, School Medicine Ethics Committee approved this study for Research on Human subjects (local protocol case 303/15 and Brazil platform CAAE number: 47882615.8.0000.0065). The study followed the recommendations of Declaration of Helsinki (1975) for the study in humans and follow ethics, consent and permissions practices. Sixteen overweight and obese boys (age: 7-10 y, body mass index (BMI) $>$ than 95th percentile according to Center for Disease Control and Prevention (CDC); 35.5 \pm 7.4 body fat percentage) were submitted to study8. The participants were without medications. The physical examination of the children included evaluation of total body mass, height, BMI, and pubertalstage. All exercise tests were performed on separate days (day 1: blood analysis measurements and skinfold assessment; and (day 2: cardiopulmonary exercise test). The inclusion criteria for the participants were: (i) to be overweight or obese, (ii) to be between the ages of 7 and 10 years old; (iii) to perform all assessments; (iv) parents' consent to participate in the study. Exclusion criteria were: (i) individuals with diabetes (type 1 or 2); (ii) renal dysfunction; (iii) hypertension; (iv) inability to perform physical exercise due to orthopedic lesions.

\section{Anthropometric assessment}

Measurements of weight and height were carried out according to described standard techniques ${ }^{9}$, with the participants in light clothes and barefoot. Weight was measuredto the nearest $0.05 \mathrm{~kg}$ and height $(\mathrm{cm})$ was measured to the nearest $0.1 \mathrm{~cm}$ by using a scale balance with incorporated stadiometer (Filizola ${ }^{\mathrm{TM}}$, Brazil). Body mass index (BMI) was calculated from weight and height measurements according to the formula: BMI $\mathrm{kg} / \mathrm{m}^{2}=$ weight/ (height $^{2}$ ) and classified according to the CDC/National Center for Health Statistics (NCHS) BMI chart for boys (2 to 20 years).

Body composition assessment was accomplished using a Lange skinfold caliper (Cambridge Scientific Industries ${ }^{\mathrm{TM}}$, Cambridge, Massachusetts, USA) for measurements of triceps, biceps, subscapular, and suprailiac skinfolds.Skinfold thickness was measured on the right side of the body to the nearest $0.1 \mathrm{~mm}$ in triplicate. Body fat and fat-free masses were estimated using the equations of Brook ${ }^{10}$ for body density of children from 1 to 11 years old and the following equation of Siri ${ }^{11}$ to calculate body fat percent of total body weight: $\%$ body fat $=[(4.95 /$ density $)$ -4.5] x 100. Lean body mass was calculated subtracting fat mass from total body weight. All skinfold thickness measurements were carried out by the same trained investigator. Intraobserver technical errors of measurement were smaller than $1 \mathrm{~mm}$ and reliability greater than $95 \%$.

\section{Biochemical analysis}

Blood tests assessments were performed before the beginning of intervention and within 48-72 h after last training session.
Blood samples for assessing haematological and biochemical parameters were collected in plain vacuum tubes from a forearm vein with minimum stasis. The individuals were in a seated position during this procedure, and had previously remained at rest for approximately $15-\mathrm{min}$. The samples were taken between 8:00 and 9:30 am, after overnight fasting and at least 24 hours since the last workout. An aliquot of $20 \mathrm{ml}$ from the venous blood sample was immediately mixed with Ethylenediaminetetraacetic acid (EDTA) solution to prevent clotting, for blood testing. The rest of the sample was left to coagulate for 30-min at room temperature and was centrifuged at $1500 \mathrm{x} g$ for $10 \mathrm{~min}$ in order to separate the serum for biochemical analysis. The serum was stored at $-20^{\circ} \mathrm{C}$ in our hospital laboratory. We performed all assays by means of commercially available diagnostic kits and using worldwide accepted techniques ${ }^{12}$.

\section{Cardiorespiratory fitness}

Cardiopulmonary exercise testing was assessed on a motordriven treadmill ( $\mathrm{h} / \mathrm{p} / \operatorname{cosmos}^{\mathrm{TM}}$, pulsar, Nussdorf-Traunstein, South of Germany) before and after completed futsal training program using a ramp-incremental modified Heck protocol. After two pilot tests with different speeds (3.6, 4.8, 6, 6.5, and $7.2 \mathrm{~km} \cdot \mathrm{h}^{-1}$ ) the test treadmill speed remained constant at a speed selected by the subject, and slope increments at the rate of $2 \%$ per minute ${ }^{13}$. Once speed had been selected, individuals remained for 2-minute at rest and shortly thereafter began the protocol at the previously chosen and tested speed. During the 6-minute recovery phase, starting immediately after the end of the examination, the speed and incline gradually decreased until the third minute, and from the fourth to the sixth minute the treadmill remained stationary. Minute ventilation $\left(\mathrm{V}_{\mathrm{E}}\right)$, respiratory exchange ratio and oxygen consumption $\left(\mathrm{VO}_{2}\right)$ were measured using an oxygen analyser monitored by a breath-bybreath system (CPX, Ultima, Medical Graphics ${ }^{\mathrm{TM}}$, St Paul, MN, USA). This metabolic cart measures expired airflow by means of a pneumotach connected to the mouthpiece. A sample line is connected to the pneumotach from which air is continuously pumped to $\mathrm{O}_{2}$ and $\mathrm{CO}_{2}$ gas analyzers. Prior to testing, the pneumotach was calibrated with ten samples from a $3-\mathrm{L}$ calibration syringe. The gas analyzers were also calibrated before each test to room air and medically-certified calibration gases $\left(12.0 \% \mathrm{O}_{2}\right.$ and $5 \% \mathrm{CO}_{2}$, respectively). An electrocardiographic signal (ECG) was recorded throughout the test. $\mathrm{VO}_{2}$ max was assessed by the attainment of the following criteria: (a) presence of $\mathrm{VO}_{2}$ plateau $\left(\Delta \mathrm{VO}_{2}\right.$ between two consecutive stages of less than $\left.2.1 \mathrm{~mL}^{\mathrm{kg}} \mathrm{kg}^{-1} \cdot \mathrm{min}^{-1}\right)$; (b) terminal Heart rate (HR) $\geq 90 \%$ of the age-predicted HRmax by Tanaka equation [208-(0.7*age)] compared with symptom-limiting termination of the test; (c) maximal respiratory exchange ratio $\left(\mathrm{RERmax}=\mathrm{VCO}_{2} / \mathrm{VO}_{2}\right) \geq 1.05$ at peak exercise; (d) maximum voluntary exhaustion defined by attaining score $\geq 18$ on Borg scale ${ }^{6-20}$ rating. All subjects met the first three criteria. In addition, data from the $\mathrm{VO}_{2}$ maxtests were time-averaged using 30-s intervals. 


\section{Training follow-up and training intervention}

The intervention consisted of 16-weeks of supervised indoor recreational futsal training and was inspired by previous studies showing comparable effects of 12-weeks of football (soccer) ${ }^{14-15}$. During the 60 minutes of training, the exercises were $100 \%$ performed with ball. Futsal training consisted of warm-up (5-min) in displacements with ball, main session (50-min) and cool-down (5-min). The futsal coach used a lot of strategy to encourage relaxing and at the same time leave the children concentrated in the exercises with the ball.The quantity of training was decisive for this outcome, i.e. the frequency, duration and the volume of training.

\section{Heart Rate Monitoring}

An adequate cardiac output must be sustained to provide sufficient blood flow throughout the body. The HR control of the child was continuously monitored in real-time using a wireless HR monitoring system. The data were archived from the heart rate monitoring system, Polar RS300X (Polar Electro ${ }^{\mathrm{TM}}$, Kemple, Finland). Each child was assigned to a numbered chest strap transmitter from the Polar Team system. All training sessions were recorded and stored on each individual heart rate transmitter until the data was uploaded. The participants were only expected to wear their assigned chest strap monitor while performing their sport required trainings. At the end of each week, an exercise physiologist would examine the physiological responses for each individual and determine how to progress the training for the subsequent week. The heart rates of children's futsal players were recorded during: first phase for specific exercises (5-minutes that served as warm-upperformed with low intensity exercise using the ball); second phase during games with official rules, played 4 vs 4 (10 minutes), 3 vs. 3 and 2 vs. 2 ( 4 minutes), with a 4-minute pause between each repetition for physical recovery and hydration. The last 5-minutes of session were a cool-down, during which the children played low-intensity games. Therefore, it was possible in each 60-minute session to repeat two passages of the procedures. During the training exercises, the coach guided the actions of the players, allowing occur little breaks so players were not induced fatigue state. Training program consisted of two sessions/week with average intensity $76 \pm 6 \%$ (range: $57-88 \%$ ) of the age-predicted (HRmax) adopting a structure of high-intensity interval training program for pediatric population. Individual portable HR monitor controlled training intensity according to the determined heart rate target calculated from Tanaka equation16. A trained futsal coach was present during all sessions in order to control the duration of the training and to ensure games exercises. Brief passive rest recovery $(<30-\mathrm{s})$ was incorporated intermittently to allow the coach's instructions on exercises could be improved.

\section{Statistical analyses}

The Gaussian distribution (normality) for the data was verified by the Kolmogorov-Smirnov goodness-of-fit test $(\mathrm{Z}$ value $<1.0$ ). Paired Student t-test for pre and post-training comparison with significance level at $\mathrm{p}<0.05$. Pearson's correlation coefficient (r) was used to verify association between metabolic and lipid profiles and body composition. Cohen's d effect sizes (ES) thresholds values were classified as (small $0.2-0.4$, moderate $0.5-0.7$, large $0.8-1.1$, very large $1.2-1.8$ and extremely large $\geq 4.0$, respectively) were used for compare the variables after intervention. Defined d as the difference between the means, M1 - M2, divided by standard deviation, SD (d = M1 - M2/ $\mathrm{SD}$ ), of either group. Cohen argued that the standard deviation of either group could be used when the variances of the two groups are homogeneous.Data are presented as mean \pm standard deviation (SD); Statistical analyses were performed using Sigma Stat (version 3.5, Systat Software, Inc, Point Richmond, CA).

\section{Results}

Anthropometric data, body composition parameters and $\mathrm{VO}_{2} \max$

Total body mass and height increased continuously during the study period. No differences were found in BMI that remained nearly constant (Table 1). After 16-weeks of recreational futsal, lean body mass $(L B M)$ was $1.9 \mathrm{~kg}$ higher $(\mathrm{p}<0.01)$ than pre-futsal program; $\mathrm{d}=$ 0.45 , small effect size. Total body weight was higher $(\mathrm{p}<0.02)$ after this period; $d=0.21$, small effect size (Table 1). No differences were observed in body mass index; $d=0.55$, moderate effect size (Table 1 ). Body fat percentage was smaller $(\mathrm{p}<0.01) 6 \%$ over intervention; $\mathrm{d}=$ 0.29 , small effect size. In post futsal training, maximal oxygen uptake $\left(\mathrm{VO}_{2} \max \right)$ was $11 \%$ higher $(\mathrm{p}<0.01)$ after 16 -weeks intervention; $\mathrm{d}$ $=0.68$, moderate effect size (Table 1 ). No association was found between body composition and metabolic variables.

Table 1. Body composition and $\mathrm{VO}_{2}$ max before (pre) and after (post) intervention in the recreational futsal training program

\begin{tabular}{|c|c|c|c|c|c|}
\hline Variable & $\begin{array}{l}\text { Pre 0 } \\
\text { weeks } \\
(\mathrm{N}=16)\end{array}$ & $\begin{array}{c}\text { Post } 16 \\
\text { weeks } \\
(\mathrm{N}=16)\end{array}$ & CI 95\% & $\begin{array}{c}\text { (Cohen's } \\
\text { d ES) }\end{array}$ & $\begin{array}{l}\text { Paired } \\
\text { t-test } \\
\mathbf{P} \\
\text { value }\end{array}$ \\
\hline $\begin{array}{l}\text { TBM } \\
(\mathrm{kg})\end{array}$ & $47.6 \pm 11.1$ & $49.4 \pm 11.3$ & $\begin{array}{l}-3.087 \text { to } \\
-0.488\end{array}$ & 0.21 & 0.010 \\
\hline $\begin{array}{l}\text { Height } \\
(\mathrm{cm})\end{array}$ & $139 \pm 7.8$ & $143 \pm 7.6$ & $\begin{array}{l}-4.403 \text { to } \\
-3.222\end{array}$ & 0.52 & 0.001 \\
\hline $\begin{array}{c}\text { BMI }(\mathrm{kg} / \\
\left.\mathrm{m}^{2}\right)\end{array}$ & $24.6 \pm 0.1$ & $24.4 \pm 0.5$ & $\begin{array}{l}-0.06 \text { to } \\
0.46\end{array}$ & 0.55 & 0.127 \\
\hline BF (\%) & $36.2 \pm 7.7$ & $34.2 \pm 7.9$ & $\begin{array}{l}0.258 \text { to } \\
3.576\end{array}$ & 0.29 & 0.026 \\
\hline $\begin{array}{c}\mathrm{LBM} \\
(\mathrm{kg})\end{array}$ & $29.0 \pm 4.1$ & $31.2 \pm 4.0$ & $\begin{array}{l}-2.743 \text { to } \\
-1.594\end{array}$ & 0.45 & 0.001 \\
\hline $\begin{array}{c}\mathrm{VO}_{2} \max \\
\left(\mathrm{mL}^{-k g^{-1}} \text {. }\right. \\
\left.\min ^{-1}\right)\end{array}$ & $27.6 \pm 4.6$ & $30.6 \pm 4.2$ & $\begin{array}{l}-5.503 \text { to } \\
-0.610\end{array}$ & 0.68 & 0.018 \\
\hline
\end{tabular}




\section{Biochemical Analysis}

No differences were observed in blood lipid and metabolic profiles between pre and post futsal training program (Table 2).

Table 2. Lipid and metabolic profiles before (pre) and after (post) intervention in the recreational futsal training program

\begin{tabular}{|c|c|c|c|c|c|c|}
\hline Variable & $\begin{array}{c}\text { Pre } 0 \\
\text { weeks } \\
(\mathrm{N}=16)\end{array}$ & $\begin{array}{l}\text { Post } 16 \\
\text { weeks } \\
(\mathrm{N}=16)\end{array}$ & $\begin{array}{c}\text { CI } \\
95 \%\end{array}$ & $\begin{array}{c}\text { (Cohen's } \\
d \text { ES) }\end{array}$ & $\begin{array}{c}\text { Paired } \\
\text { t-test } \\
P \\
\text { value }\end{array}$ & $\begin{array}{c}\text { Reference } \\
\text { values in } \\
\text { blood }\end{array}$ \\
\hline $\begin{array}{c}\mathrm{TC}(\mathrm{mg} / \\
\mathrm{dL})\end{array}$ & $176 \pm 27$ & $168 \pm 30$ & $\begin{array}{c}-1.190 \\
\text { to } \\
17.315\end{array}$ & 0.20 & 0.083 & $<244$ \\
\hline $\begin{array}{l}\text { HDL-c } \\
(\mathrm{mg} / \mathrm{dL})\end{array}$ & $49 \pm 12$ & $50 \pm 10$ & $\begin{array}{c}-4.337 \\
\text { to } \\
3.087\end{array}$ & 0.10 & 0.725 & $35-84$ \\
\hline $\begin{array}{l}\text { LDL-c } \\
(\mathrm{mg} / \mathrm{dL})\end{array}$ & $118 \pm 28$ & $108 \pm 34$ & $\begin{array}{c}1.101 \\
\text { to } \\
18.024\end{array}$ & 0.19 & 0.029 & $<136$ \\
\hline $\begin{array}{l}\text { VLDL-c } \\
(\mathrm{mg} / \mathrm{dL})\end{array}$ & $19 \pm 13$ & $17 \pm 8$ & $\begin{array}{c}-2.280 \\
\text { to } \\
5.405\end{array}$ & 0.18 & 0.400 & $<40$ \\
\hline $\begin{array}{c}\text { TRI } \\
(\mathrm{mg} / \mathrm{dL})\end{array}$ & $96 \pm 6$ & $88 \pm 38$ & $\begin{array}{c}-11.319 \\
\text { to } \\
26.694\end{array}$ & 0.09 & 0.402 & $<137$ \\
\hline $\begin{array}{c}\text { GLU } \\
(\mathrm{mg} / \mathrm{dL})\end{array}$ & $86 \pm 6$ & $86 \pm 5$ & $\begin{array}{c}-4.497 \\
\text { to } \\
4.372\end{array}$ & 0.18 & 0.976 & $60-110$ \\
\hline $\begin{array}{c}\mathrm{In} \\
(\mathrm{mU} / \mathrm{L})\end{array}$ & $10.1 \pm 5.4$ & $11.5 \pm 6.5$ & $\begin{array}{c}-3.683 \\
\text { to } \\
0.833\end{array}$ & 0.32 & 0.198 & $1.8-24.6$ \\
\hline
\end{tabular}

Abbreviations: TC, Total cholesterol; HDL-c, high-density lipoprotein; LDL-c, low-density lipoprotein; VLDL, Very-low-density lipoprotein; TRI, Triglycerides; GLU, Glucose; In, insulin. $d$ effect size (ES): small, 0.20-0.4; moderate, $0.5-0.8$; large $0.8-1.1$, very large 1.2-1.8 and extremely large $\geq$ 4.0. Values are presented as mean $\pm 95 \%$ CI.

\section{The intervention pilot attendance and Training intensity}

The attendance rate during the intervention pilot was $80 \%$ at the end of the program and corresponded to a mean of 26 training sessions per child during the whole study period. Exercise intensity $\geq 76 \%$ of HRmax was recorded during $60 \mathrm{~min} / \mathrm{session}$. Training intensity was quantified by means of heart rate monitoring several times for each child. For each individual, heart rate was recorded during an average of 20 training sessions ( $63 \%$ of total training time). The mean training heart rate was $153 \pm 11$ beats/min, corresponding to $76 \pm 6 \% \mathrm{HRmax}$ (range: 57 - 88\%). Estimated energy expenditure (from gas exchange and heart rate data during treadmill exercise test) was $1.523 \pm 184 \mathrm{~kJ}(364 \pm 44 \mathrm{kcal})$ per training session.

\section{Discussion}

The present study highlights the positive effects of futsal training on body composition and aerobic power of the overweight and obese children. Traditional soccer has shown several effects on health parameters ${ }^{17}$. However, no other studies assessing recreational futsal in overweight and obese children were found in the literature. Therefore, our data are compared to soccer as sport similar to futsal.

Nevertheless, the present study showed that futsal training is an effective way of obtaining improvements in performance and significant physiological adaptations ${ }^{18}$. Additionally, our findings suggest that the positive aspects of recreational futsal and theresults from this research may be used in sustainable environments such as the school's physical education classes. In addition, it may be an alternative activity for other chronic diseases once soccer has already been employed with this aim. Various studies have shown the effects of traditional soccer on several performance variables in children and adults ${ }^{19-20}$. In contrary, studies on futsal with overweight and obese children are scarce ${ }^{21}$.

In the present study the children showed significant changes in body composition, specifically a decrease in $\mathrm{TBF}, \mathrm{BF} \%$, and increase LBM. Other studies have reported small differences with different levels of intensity in the lipid profile. Therefore, it is unclear to what extent exercise intensity influences lipemia. However, another study showed that young Italian male soccer players presented a high inter-individual variability of pubertal stage within the same class of chronological age $\mathrm{a}^{20}$. This can explain in part by the variability of the physical parameters (TBF, $\mathrm{BF} \%, \mathrm{LBM})$ in this population ${ }^{22}$. Although exercise training could improve the lipid profile, not difference was found in present study. The possible mechanism that might explain why lipid profile was not modified after intervention is linked to hypothesis that the interaction between Lipoprotein (a) and Apo B100 and other cardiovascular risk factors suggests that high intensity mixed sports with a strong dynamic component, eccentric muscle contractions and high muscle and joint impact, such as soccer, may be associated with less favorable lipid profile, as postulated by Houmard, Tanner, Slentz, Duscha, McCartney, Kraus ${ }^{23}$. In the report of Ostrowsky, Rohde, Asp, Schjerling, Pedersen ${ }^{24}$ it is believed that intense exercise, particularly eccentric exercise accompanied by falls and collisions frequency, the soccer leads to the release of proinflammatory cytokines associated with abnormalities in metabolism. Addittionally, conditionssuch as training volume, frequency of sessions (120 min/wk) and dietary control alsointerfere in the response of the lipidparameters.It has been shown that the training duration of $170 \mathrm{~min} / \mathrm{wk}$ induces greater effects than $117 \mathrm{~min} / \mathrm{wk}$. According to a meta-analysis study it is recommended longer duration $(155-180 \mathrm{~min})$ to positively affect fat reduction in overweight children ${ }^{25}$. However, in the present study $120 \mathrm{~min} / \mathrm{wk}$ was minimal time sufficient to decrease body fat and increase LBM, respectively. Although the ACSM and AHA time recommendations for training were not met, the effects of shorter duration in the present study were efficient to elicit beneficial effects with less time to maintain aerobic fitness ${ }^{26}$.

The current findings of the present study, although in a small sample provide further evidence that playing futsal has significant health effects. Although in this study the metabolic profile was not altered, futsal interventions were effective in improving 
cardiorespiratory fitness increasing $\mathrm{VO}_{2} \max$. In the present study the children had an improvement of $11 \%$ in $\mathrm{VO}_{2}$ max and this result was similar to that found by Faude et. al. ${ }^{27}$ in overweight children playing traditional football. In addition, the small side games performed within the futsal sessions are as effective as performing running interval training. Intensity of futsal sessions in our study was high. Average heart rate was 153 beats $/ \mathrm{min}$, which is equivalent to $76 \%$ of MHR (maximum heart rate). Therefore, they are positive in improving and maintaining the aerobic fitness ${ }^{28}$.

Results indicated during specific drills of the 2 versus 2 and 3 versus 3, and less 4 versus 4 yielded significantly higher ball touches highlight the importance of utilizing smaller-sided games to promote greater energy expenditure by increasing ball engagement ${ }^{29}$. Therefore, physiological effects of duration and variations in the numbers of children in futsal specific drills is a strategy that should be adopted ${ }^{29}$. Results of our study could be a way to motivate the training, since it was conducted only for two days in a week with just 60-minutes duration with positive effect on markers of body composition and cardiorespiratory fitness. Multidimensional efforts must continue to promote the prevention and treatment of overweight and obesity. Sport is a cheap tool. In the study, the type of futsal training done was not exactly the competitive game we see on television. We emphasize that this type of match can be played by everyone, regardless of age, sex, level of futsal experience and physical fitness.

\section{Conclusion}

In conclusion, 16-week futsal training program were determinant to enhance body composition, and cardiorespiratory fitness in this group of prepubertal boys.

\section{Study limitations}

We recognize that some limitations exist for the present study: a) the small number of participants, b) the lack of control group, and c) the non-randomization of the participants. Although we have used futsal, soccer has shown that studies with smaller sample have shown positive effects when practiced regularly regardless of gender, age or health conditions.Thus, future research should compare the effects of recreational futsal with high-intensity interval training on health-related physical fitness and enjoyment in children. Given so far, few studies with futsal in children, further research should explore the effectiveness of recreational futsal training on physical fitness in longer training periods and with a larger sample size. Therefore, the findings from this study should not be generalized.

\section{Perspectives}

In times of growing obesity in the world, affecting millions of children largely due to chronic physical inactivity, futsal has potential benefit for health and wellness promotion and can be incorporated as part of the total amount of physical activity that children can do all the days together with physical education classes or even as leisure ${ }^{30}$. This project with futsal was the kickoff to aims to reinforce the role of futsal as it is already a reality his great brother soccer as a means of promoting good health. The health of the children can be improved with the right nutrition and sufficient exercise regularly ${ }^{31}$. To achieve this goal, an adequate exercise should be created for all age groups, and the futsal can be incorporated, including in schools. Our study was conducted with a small group of individuals. It is necessary to reproduce it in a larger group, with more time of accompaniment. Anyway, the result obtained is quite promising.

\section{References}

1. Moore R, Bullough S, Goldsmith S, Edmondson L. A systematic review of futsal literature. Am J of Sports Sci and Med.2014; 2(3):108-16.

2. Krustrup P, Hansen PR, Nielsen CM, Larsen MN, Randers MB, Bangsbo J, Dvorak J, Hansen L, Manniche V. Structural and functional cardiac adaptations to a 10week school-based football intervention for 9-10-year-old children. Scand J Med Sci Sports.2014; Suppl 1: 4-9.

3. Bangsbo J, Hansen PR, Dvorak J, Krustrup P. Recreational football for disease prevention and treatment in untrained men: a narrative review examining cardiovascular health, lipid profile, body composition, muscle strength and functional capacity. Br J Sports Med. 2015;49(9): 568-76.

4. Madsen K, Thompson H, Adkins A, Crawford Y. School-Community Partnerships. A cluster-randomized trial of an after-school soccer program. JAMA Pediatr. 2013;167(4):321-26.

5. Sacheck JM, Nelson T, Ficker L, Kafka T, Kuder J, Economos CD. Physical activity during soccer and its contribution to physical activity recommendations in normal weight and overweight children. Pediatr Exerc Sci. 2011; 23(2):281-92.

6. Hallal PC, Andersen LB, Bull FC, Guthold R, Haskell W, Ekelund U. Lancet Physical Activity Series Working Group. Global physical activity levels: surveillance progress, pitfalls, and prospects. Lancet. 2012; 380(9838): 247-57.

7. Serpiello FR, McKenna MJ, Coratella G, Markworth JF, Tarperi C, Bishop D, et al. Futsal and continuous exercise induce similar changes in specific skeletal muscle signalling proteins. Int J Sports Med. 2014;35(10):863-70.

8. Strasburger VC, Hogan MJ, American Academy of Pediatrics Committee on Public Education. Children, adolescents, and the media. Pediatrics. 2013;132:958-61.

9. Gordon CC, Chumlea WC, Roche AF. Stature, recumbent length, and weight. In: Lohman TG, Roche AF, Martorell $\mathrm{R}$, editors. Anthropometric standardization reference manual. Champaign: Human Kinetics (1988). p.3-8 
10. Brook CGD. Determination of body composition of children from skinfold measurements. Arch Dis Child. 1971; 46:182-4.

11. Siri WE. Body composition from fluid spaces and density. MS UCRL 3349. Donner Laboratory, University of California, 1956.

12. Nikolaidis MG, Protosygellou MD, Petridou A, Tsalis G, Tsigilis N, Mougios V. Hematologic and biochemical profile of juvenile and adult athletes of both sexes: implications for clinical evaluation. Int J Sports Med. 2003; 24:506-11.

13. Muotri RW, Bernik MA. Panic disorder and exercise avoidance. Rev Bras Psiquiatr. 2014; 36(1):68-75.

14. Krustrup P, Aagaard P, Nybo L, Petersen J, Mohr M, Bangsbo J. Recreational football as a health promoting activity: a topical review. Scand J Med Sci Sports. 2010a; 20(Suppl. 1): 1-13.

15. Krustrup P, Christensen JF, Randers MB, Pedersen H, Sundstrup E, Jakobsen MD, Krustrup BR, Nielsen JJ, Suetta C, Nybo L, Bangsbo J.Muscle adaptations and performance enhancements of soccer training for untrained men. Eur J Appl Physiol. 2010b; 108: 1247-58.

16. Tanaka H, Monahan KD, Seals DR. Age-predicted maximal heart rate revisited. J Am Coll Cardiol. 2001;37:153-6.

17. Hammami A, Chamari K, Slimani M, Shephard RJ, Yousfi N, Tabka Z. Effects of recreational soccer on physical fitness and health indices in sedentary healthy and unhealthy subjects. Biol Sport. 2016; 33(2):127-37.

18. Alvarez JC, D’Ottavio S, Vera JG, Castagna C. Aerobic fitness in futsal players of different competitive level.J Strength Cond Res. 2009;23(7):2163-6.

19. Nikolaïdis PT. Overweight and obesity in male adolescent soccer players. Minerva Pediatr. 2012; 64(6): 615-22

20. Calcaterra V, Larizza D, Codrons E, De Silvestri A, Brambilla P, Abela S, et al. Improved metabolic and cardiorespiratory fitness during a recreational training program in obese children. J Pediatr Endocrinol Metab. 2013; 26(3-4): 271-6.

21. Nikolaidis PT, Karydis NV. Asian physique and body composition in soccer players across adolescence. J Sports Med. 2011;2(2):75-82.

22. Bolivar J, Sandoval O, Osorio J, Dib G, Gallo J. Relationship of chronological age and sexual maturity with skeletal maturity by magnetic resonance imaging of the distal radial epiphysis in adolescent football players. Apunts Med Esport. 2015; 50(188): 129-37.

23. Houmard JA, Tanner CJ, Slentz CA, Duscha BD, McCartney JS, Kraus WE. Effect of the volume and intensity of exercise training on insulin sensitivity. J Appl Physiol. 2004; 96: 101-6.

24. Ostrowsky K, Rohde T, Asp S, Schjerling P, Pedersen BK. Proand anti-inflammatory cytokine balance in stressful exercise in humans.J Physiol. 1999; 515: 287-91.
25. Los Arcos A, Vázquez JS, Martín J, Lerga J, Sánchez F, Villagra F, Zulueta JJ. Effects of small-sided games vs. interval training in aerobic fitness and physical enjoyment in young elite soccer players. PLoS One. 2015; 10(9): e0137224.

26. Duncan JJ, Gordon NF, Scott CB. Women walking for health and fitness: how much is enough? JAMA.1991; 266(23): 3295-9.

27. Faude O, Kerper O, Multhaupt M, Winter C, Beziel $\mathrm{K}$, Junge A, Meyer T.Football to tackle overweight in children. Scand J Med Sci Sports. 2010; 20 (Suppl. 1): 103-110.

28. Van der Horst K, Paw MJCA, Twisk JW, Van Mechelen W. A brief review on correlates of physical activity and sedentariness in youth. Med Sci Sports Exerc. 2007; 39(8): 1241-50.

29. Bell K, Johnson TG, Shimon JM, Bale J. The effects of game size on the physical activity levels and ball touches of elementary school children in physical education. Journal of Kinesiology \& Wellness (2013); 2.

30. Ebbeling CB, Pawlak DB, Ludwig DS. Childhood obesity: public-health crisis, common sense cure. The Lancet. 2002;360(9331):473-482.

31. Purcell LK and Canadian Paediatric Society, Paediatric Sports and Exercise Medicine Section. Sport nutrition for young athlete.Paediatr Child Health. 2013;18(4): 200-202.

\section{Acknowledgments}

We thank all children and parents for their kind participation in our study.

\section{Corresponding author}

Paulo Roberto Santos - Silva

Laboratório de Estudos do Movimento, Instituto de Ortopedia e Traumatologia do HC/FMUSP

Rua Dr. Ovídio Pires de Campos, 333, $2^{\circ}$ andar, Cerqueira César CEP: 05403-010 São Paulo/SP, Brazil

Email: fisiologistahc@yahoo.com.br

Manuscript received on March 9, 2018

Manuscript accepted on April 25, 2018

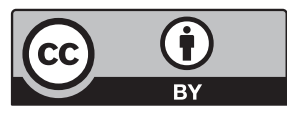

Motriz. The Journal of Physical Education. UNESP. Rio Claro, SP, Brazil

- eISSN: 1980-6574 - under a license Creative Commons - Version 3.0 